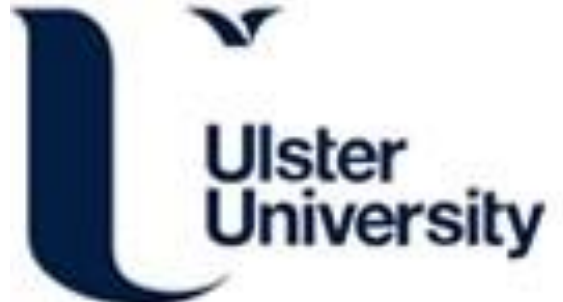

\section{Identification of transformation products of carbamazepine in lettuce crops irrigated with Ultraviolet-C treated water}

Martínez-Piernas, A. B., Nahim-Granados, S., Polo-López, M. I., Fernández-lbáñez, P., Murgolo, S., Mascolo, G., \& Agüera, A. (2019). Identification of transformation products of carbamazepine in lettuce crops irrigated with Ultraviolet-C treated water. Environmental Pollution, 247, 1009-1019.

https://doi.org/10.1016/j.envpol.2019.02.001

Link to publication record in Ulster University Research Portal

\section{Published in:}

Environmental Pollution

Publication Status:

Published (in print/issue): 01/04/2019

DOI:

10.1016/j.envpol.2019.02.001

\section{Document Version}

Author Accepted version

\section{General rights}

Copyright for the publications made accessible via Ulster University's Research Portal is retained by the author(s) and / or other copyright owners and it is a condition of accessing these publications that users recognise and abide by the legal requirements associated with these rights.

\section{Take down policy}

The Research Portal is Ulster University's institutional repository that provides access to Ulster's research outputs. Every effort has been made to ensure that content in the Research Portal does not infringe any person's rights, or applicable UK laws. If you discover content in the Research Portal that you believe breaches copyright or violates any law, please contact pure-support@ulster.ac.uk. 
1 Identification of transformation products of carbamazepine in lettuce crops irrigated with Ultraviolet-C treated water

3

4 A.B. Martínez-Piernas ${ }^{1}$, S. Nahim-Granados ${ }^{2}$, M.I. Polo-López ${ }^{2}$, P. Fernández-Ibáñez ${ }^{3}$, 5 S. Murgolo ${ }^{4}$, G. Mascolo ${ }^{4}$, A. Agüera ${ }^{1}$

$6{ }^{1}$ CIESOL, Joint Centre University of Almeria-CIEMAT, Carretera de Sacramento $s / n$, $7 \quad$ E-04120, Almeria, Spain

82 Plataforma Solar de Almería-CIEMAT, Carretera Senés km 4, 04200 Tabernas,

9 Almería, Spain

$10{ }^{3}$ Nanotechnology and Integrated BioEngineering Centre, School of Engineering,

11 University of Ulster, Newtownabbey, Northern Ireland, United Kingdom

$12{ }^{4}$ CNR, Istituto di Ricerca Sulle Acque, Via F. de Blasio 5, 70132, Bari, Italy 


\section{Abstract}

Transformation of organic microcontaminants (OMCs) during wastewater treatments results in the generation of transformation products (TPs), which can be more persistent than parent compounds. Due to reuse of reclaimed wastewater (RWW) for crop irrigation, OMCs and TPs are released in soils being capable to translocate to crops. Furthermore, OMCs are also susceptible to transformation once they reach the soil or crops. The recalcitrant antiepileptic carbamazepine (CBZ) and some of its frequently reported TPs have been found in agricultural systems. However, there is no knowledge about the fate in reuse practices of multiple CBZ TPs that can be formed during wastewater treatment processes. For the first time, this work presents a study of the behavior of CBZ TPs generated after a conventional Ultraviolet-C (UVC) treatment in an agricultural environment. The UVC-treated water was used for the irrigation of lettuces grown under controlled conditions. The latter was compared to the fate of TPs generated in the peat and plant by irrigation with non-treated water containing CBZ. A suspect screening strategy was developed to identify the TPs using liquid chromatography coupled to quadrupole-time-of-flight (LC-QTOF-MS). The results revealed the presence of 24 TPs, 22 in UVC-treated water, 11 in peat and 9 in lettuce leaves. 4 of the TPs identified in peat (iminostilbene, TP 271B, TP 285A-B); and 3 in leaves (10-11 dihydrocarbamazepine, TP 271A-B) were not previously reported in soils or edible parts of crops, respectively. Comparing the TPs found in peat and lettuces derived from both irrigation conditions, no significant differences regarding TPs formation or occurrence were observed. UVC treatment did not contribute to the formation of different TPs than those generated by transformation or metabolism of CBZ in peat or plant material. This research improves the current knowledge on the fate of CBZ TPs in agricultural systems as a consequence of reuse practices.

Keywords: Carbamazepine, transformation products, LC-QTOF-MS, wastewater reuse, suspect screening 
44

Nowadays, standard treatment processes applied in wastewater treatment plants (WWTPs) do not remove efficiently a large variety of organic microcontaminants (OMCs) as pharmaceuticals, personal care products or pesticides (Campos-Mañas et al., 2017). With OMCs, several recalcitrant transformation products (TPs), generated during the treatments, are continuously discharged in WWTP effluents (Schollée et al., 2015). As agricultural practices demand a large amount of water, reuse of reclaimed wastewater (RWW) has become a common practice in many dry areas to deal with water shortages. Consequently, OMCs and TPs have been reported in agricultural soils at concentrations up to $\mu \mathrm{g} \mathrm{g}^{-1}$ (Chen et al., 2011; Christou et al., 2017; Kinney et al., 2006; Koba et al., 2016). Due to their physical-chemical properties, some of these compounds have the potential to be uptaken via plant roots (Wu et al., 2015). Once compounds have entered the plant, a subsequent translocation toward other parts of plants, including the edible part of crops, can take place resulting in the possible introduction of undesirable substances into the food chain. Although the number of studies dedicated to soil accumulation and plant uptake of OMCs is steadily increasing in recent years (Carter et al., 2018; Larivière et al., 2017; Martínez-Piernas et al., 2018a), little information is available regarding TPs behavior in soil/plant systems. These TPs often present similar or even greater concentration levels than their parent compounds in WWTP effluents (Bahlmann et al., 2014). Additionally, they can be also generated in soils from biotic/abiotic transformations and in crops as a consequence of the metabolism of plants (Huynh et al., 2018; Riemenschneider et al., 2017). Considering that some TPs have analogous or even more severe biological activity than parent compounds (Brezina et al., 2017), their fate and ecotoxicological and human health risks merit further research.

Generally, TPs show very diverse physical-chemical properties due to their different structures. For this reason, broad spectrum extraction methodologies are required to obtain efficient recoveries in a wide range of compounds . QuEChERS (Quick, Easy,Cheap, Effective, Rugged and Safe) and pressurized liquid extraction (PLE) have demonstrated to be good alternatives even in these complex environmental matrices (Martínez-Piernas et al., 2018b) (Jelić et al., 2009). Besides, the application of screening methodologies accomplished by liquid chromatography coupled to high resolution mass 
spectrometry (HRMS), have undoubtedly improved the identification of unexpected or not previously validated compounds by the application of non-target and suspect screening approaches ( Martínez-Piernas et al., 2018a).

Carbamazepine (CBZ) is one of the most frequently detected OMCs in WWTP effluents due to its recurrent prescription for neuropsychiatric disorders (Ambrósio et al., 2002) and its low removal by the application of standard wastewater treatment processes (Zhang et al., 2008). Because of its persistence and ubiquitous occurrence, it has been proposed as an appropriate indicator for the evaluation of anthropogenic impact on the aquatic environment (Kinney et al., 2008). According to the criteria established by Council Directive 92/32/EEC, CBZ has been classified as potentially harmful compound for aquatic organisms (Fent K., 2008). In addition, the formation of several of its TPs has been reported by the application of different wastewater treatments, which are presented in Table S1. CBZ undergoes transformation to various aldehydes, ketones and hydroxylated derivatives and known ecotoxic compounds as acridine and acridone (Donner et al., 2013). However, information about presence and fate of CBZ TPs in soils and crops is still scarce. Riemenschneider et al. (Riemenschneider et al., 2017) investigated the formation and translocation of CBZ TPs through the different parts of tomato plants irrigated with a spiked solution of CBZ under hydroponic conditions. Regarding soils, Koba et al. (Koba et al., 2016) evaluated the stability of CBZ in different soils, identifying in samples up to three TPs after an incubation process with CBZ. Nevertheless, to our knowledge, no data is available about the fate of CBZ TPs produced after standard tertiary treatments in agricultural systems. Regarding tertiary treatments, advanced oxidation processes (AOPs), which are characterized by the formation of powerful oxidizing species, have been proved to be effective in the degradation of organic contaminants (Malato et al., 2009). Among available AOPs, ultraviolet treatment is one of the most extended processes for drinking and wastewater purification and, in particular, degradation of CBZ by UV and UV-based AOP has been widely reported in literature (Dai et al., 2012; Deng et al., 2013; Ghasemian et al., 2017).

The objective of this study was to increase the current knowledge on the fate of CBZ TPs in an agricultural system based on a lettuce crop grown in peat under controlled conditions. The presence and fate of TPs in these two commodities were compared 
considering two different TP sources: i) TPs formed after conventional Ultraviolet-C (UVC) treatment applied to the irrigation water, and ii) TPs formed in the soil-plant system by the transformation of CBZ introduced by theirrigation water. The identification of CBZ TPs was carried out by the application of a suspect screening strategy by LC-QTOF-MS, which included up to 47 TPs commonly found after different decontamination or biological processes.

\section{Materials and methods}

\subsection{Chemicals}

Carbamazepine (CBZ), carbamazepine 10,11-epoxide (EPOX), acridone (ACRO), acridine (ACRI), oxcarbazepine $(\mathrm{OX})$ and carbamazepine- $\mathrm{d}_{10}\left(\mathrm{CBZ}-\mathrm{d}_{10}\right)$ analytical standards (purity grade $\geq 98 \%$ ) were purchased from Sigma Aldrich (Steinheim, Germany). Iminostilbene, 9-acridinecarboxylic acid, 9-acridine-carboxaldehyde and 1011 dihydrocarbamazepine (all purity $\geq 98 \%$ ) identified by suspect screening analysis and acquired for confirmatory purposes were also purchased from Sigma Aldrich. LCMS grade acetonitrile $(\mathrm{MeCN})$, methanol $(\mathrm{MeOH})$, water, formic acid and acetic acid were purchased from Sigma Aldrich. For QuEChERS, magnesium sulfate $\left(\mathrm{MgSO}_{4}\right)$, sodium acetate $(\mathrm{NaOAc})$, octadecyl silica $(\mathrm{C} 18)$ and primary-secondary amine (PSA) were purchased from Sigma Aldrich. Hydromatrix was provided by Thermo Fisher Scientific (Waltham, USA).

Stock standard solutions were prepared in $\mathrm{MeOH}$ at a concentration of $1000 \mathrm{mg} \mathrm{L}^{-1}$. A mixed working solution containing all standards was prepared at $10 \mathrm{mg} \mathrm{L}^{-1}$ in $\mathrm{MeOH}$ by proper dilution of each stock standard solution. All solutions were prepared in amber glass vials and stored at $-20^{\circ} \mathrm{C}$. CBZ-d $\mathrm{d}_{10}$ was used as extraction quality control check.

\subsection{Experimental set-up}

\subsubsection{Experimental lettuce cultivation}

Seeds of lettuce (Lactuca sativa) obtained from a local provider were cultivated under controlled conditions of temperature and humidity in an experimental greenhouse described by Martínez-Piernas et al., 2018b. 90 propylene pots $(9 \times 9 \times 10 \mathrm{~cm})$ were filled with sterilized peat (autoclaved using autoclave-bags at $121{ }^{\circ} \mathrm{C}$ during $15 \mathrm{~min}$ in 
137 batches of $5 \mathrm{~kg}$ of peat). The peat was a mixture of blond peat, black peat, coconut 138 fibers and perlite containing $\mathrm{N}, \mathrm{P}$, and $\mathrm{K}$ in a ratio (w/v) of $13-14-13 \mathrm{~g} \mathrm{~L}^{-1}$, 139 respectively, $\mathrm{pH} \mathrm{7,} \mathrm{organic} \mathrm{matter} \mathrm{dry} \mathrm{matter} \mathrm{ratio} \mathrm{of} 80 \%$, apparent density of $0.38 \mathrm{~kg}$ $140 \mathrm{~L}^{-1}$ and $120 \mathrm{mS} \mathrm{m}^{-1}$ of conductivity, according to the manufacturer. The growing crops 141 was not done under sterile conditions. The growing period was conducted from May to 142 July 2016, a total of 10 weeks. Three experimental conditions (30 pots each) were 143 performed separately to avoid any cross-contamination: a) control samples irrigated 144 with synthetic water (SW); b) samples irrigated with SW spiked with $1 \mathrm{mg} / \mathrm{L}$ of CBZ 145 (SW+CBZ); and c) samples irrigated with SW spiked with $1 \mathrm{mg} \mathrm{L}^{-1}$ of CBZ and treated 146 by UVC (SW+CBZ+UVC). Pots were irrigated every two days. The experimental setup 147 for the three cultivations of lettuce crops is shown Figure S1. The sampling strategy was 148 designed to evaluate potential presence and accumulation of CBZ and metabolites/TPs 149 in peat and lettuce leaves. A total of five sampling events occurred. Samples were taken 150 every two weeks from the second week of growth until the tenth week (harvest). In each sampling event, ten pots randomly selected were taken (leaves and peat) and combined to form a homogenized composite sample which was extracted per triplicate. The final size of lettuce leaves was $15 \mathrm{~cm}$ in the last sampling event.

\subsubsection{Irrigation water}

155

SW was prepared following the recipe published in (American Public Health Association, American Water Works Association, 2012) under the "standard moderately-hard freshwater" nomenclature, based on the characteristics of groundwater in Almería province (Spain). For the irrigation of crops with CBZ, SW was spiked with the appropriate amount of pure $\mathrm{CBZ}$ standard to reach a final concentration of $1 \mathrm{mg} \mathrm{L}^{-1}$. Before each irrigation event, a fresh solution of CBZ was prepared to avoid the possible formation of undesirable TPs. For the irrigation tests with treated-CBZ, UVC treatments were carried out in a pilot plant previously described by Miralles-Cuevas et al., 2017. Briefly, it consists of three independent low-pressure UVC lamps (254 nm peak wavelengths, $230 \mathrm{~W}$ and $40 \mathrm{~mJ} \mathrm{~cm}^{-2}$ of UV dose or fluence) serially connected to holding tank. The volume of each lamp-camera is $5 \mathrm{~L}$. In this work, the system was operated with one UVC lamp in recirculating batch mode at $30 \mathrm{~L} / \mathrm{min}$ of flow. The tank was filled with $80 \mathrm{~L}$ of SW and spiked with CBZ $\left(1 \mathrm{mg} \mathrm{L}^{-1}\right)$. After $10 \mathrm{~min}$ of mixing in the dark, a Time 0 was taken out and the UVC lamp was switched on. From this time, 
169

170

171

172

173

174

175

176

177

178

179

180

181

182

183

184

185

186

187

188

189

190

191

192

193

194

195

196

197

198

199

samples were taken every 2 min during the first $20 \mathrm{~min}$, and every $5 \mathrm{~min}$ till the end of the treatment $(60 \mathrm{~min}$ total exposure time). The treated water $(\mathrm{ca} .60 \mathrm{~L})$ was stored at $4^{\circ} \mathrm{C}$ and used for crop irrigation during one week. The same procedure was repeated weekly during the irrigation period (a total of 10 weeks) in order to use fresh-batches and avoid possible fluctuations of TPs during storage. Irrigation events occurred every two-three days depending on plant water demand, with $50 \mathrm{~mL}$ of water/pots. All water batches were analyzed by LC-QTOF-MS before irrigation to verify the absence of any compound in control water (SW), the absence of TPs in water spiked with CBZ $(\mathrm{SW}+\mathrm{CBZ})$ and possible fluctuations in the formation of TPs in treated water $(\mathrm{SW}+\mathrm{CBZ}+\mathrm{UVC})$.

\subsection{Sample preparation}

\subsubsection{Lettuce extraction}

Leaves of lettuce samples were washed with tap water, chopped and stored in the dark at $-20^{\circ} \mathrm{C}$ until their analysis. Samples were extracted by a QuEChERS-based extraction method including a dispersive solid-phase extraction (d-SPE) clean-up step (MartínezPiernas et al., 2018b). Briefly, a representative aliquot of $10 \mathrm{~g}$ of previously homogenized sample was weighed in a $50 \mathrm{~mL}$ PTFE centrifuge tube. $10 \mathrm{~mL}$ of MeCN at $1 \%$ of acetic acid and $50 \mu \mathrm{L}$ of CBZ- $\mathrm{d}_{10}\left(400 \mu \mathrm{g} \mathrm{L}^{-1}\right)$, used as internal quality control, were added and the tube was shaken for $5 \mathrm{~min}$. After that, $6 \mathrm{~g}$ of $\mathrm{MgSO}_{4}$ and $1.5 \mathrm{~g}$ of $\mathrm{NaOAc}$ were added and the tube was vigorously shaken for $5 \mathrm{~min}$ and centrifuged at $3500 \mathrm{rpm}(2054 \mathrm{~g})$ for $5 \mathrm{~min}$. Then, a $5 \mathrm{~mL}$ aliquot of the organic layer was transferred to a $15 \mathrm{~mL}$ centrifuge tube containing $125 \mathrm{mg}$ of PSA, $125 \mathrm{mg}$ of C18 and $750 \mathrm{mg}$ of anhydrous $\mathrm{MgSO}_{4}$. The tube was then shaken for $30 \mathrm{~s}$ in a Vortex and centrifuged again (3500 rpm, $5 \mathrm{~min}$ ). After that, the extracts $(4 \mathrm{~mL})$ were transferred to screw cap vials and $10 \mu \mathrm{L}$ of $\mathrm{MeCN} 1 \%$ formic acid per $\mathrm{mL}$ of extract were added. Finally, an aliquot of $150 \mu \mathrm{L}$ of the extract was evaporated until dryness and reconstituted with the same volume of $\mathrm{MeCN}: \mathrm{H}_{2} \mathrm{O}(10: 90, v / v)$ before the injection in the LC-QTOF-MS/MS system.

\subsubsection{Peat extraction}

Peat samples were homogenized, freeze dried and finally grinded using a Mixer Mill MM 301 equipped with two cells of $35 \mathrm{~mL}$ made of $\mathrm{ZrO}_{2}$. Samples were extracted by 
PLE following the protocol described in (Jelić et al., 2009) using an ASE 300

201

202

203

204

205

206

207

208

209

210

211

212

213

214

215

216

217

218

219

220

221

222

223

224

225

226

227

228

229

230

231 accelerated solvent extractor followed by a solid-phase extraction (SPE) clean-up step. 1 $\mathrm{g}$ of homogeneous freeze-dried peat was placed in a stainless steel extraction cell of 11 $\mathrm{mL}$, which was filled with hydromatrix. The extraction solvent consisted of a mixture of $\mathrm{MeOH}: \mathrm{H}_{2} \mathrm{O}(1: 2, v / v)$. Optimized PLE parameters chosen were: a temperature $100{ }^{\circ} \mathrm{C}$, a preheating period of $5 \mathrm{~min}$, a total of 3 static cycles ( 5 min each), and total flush volume of $100 \%$ of the cell with $60 \mathrm{~s}$ of nitrogen purge. PLE extract (about $40 \mathrm{~mL}$ ) was diluted in $500 \mathrm{ml}$ of $\mathrm{H}_{2} \mathrm{O}$ and cleaned-up by SPE using Oasis HLB cartridges (200 mg, $6 \mathrm{~mL}$ ). The cartridges were conditioned with $5 \mathrm{~mL}$ of $\mathrm{MeOH}$ followed by $5 \mathrm{~mL}$ of $\mathrm{H}_{2} \mathrm{O}$ at neutral $\mathrm{pH}$. The elution of compounds was carried out with $8 \mathrm{~mL}$ of $\mathrm{MeOH}$. Then, SPE extracts were evaporated under nitrogen stream and reconstituted in $1 \mathrm{~mL}$ of $\mathrm{MeCN}: \mathrm{H}_{2} \mathrm{O}(10: 90, v / v)$ before LC-QTOF-MS/MS injection.

\subsection{Analysis by liquid chromatography tandem mass spectrometry}

Chromatographic separation was carried out using a HPLC 1260 Infinity (Agilent Technologies, Palo Alto, CA, USA) system provided with an Eclipse C18 (4.6 x 150 $\mathrm{mm}, 5 \mu \mathrm{m}$ particle size) column (Agilent Technologies). The mobile phases were $0.1 \%$ formic acid in water (solvent $\mathrm{A}$ ) and pure $\mathrm{MeCN}$ (solvent $\mathrm{B}$ ). The injection volume was $20 \mu \mathrm{L}$ and the flow rate was $0.5 \mathrm{~mL} \mathrm{~min}^{-1}$. The initial proportion of solvent $\mathrm{B}$ was $10 \%$, which was kept constant for $2 \mathrm{~min}$, increased to $100 \%$ within $38 \mathrm{~min}$, kept constant for $10 \mathrm{~min}$ and reduced to $10 \%$ in $0.1 \mathrm{~min}$. The post-run equilibration time was $15 \mathrm{~min}$.

For HRMS, a TripleTOF ${ }^{\circledR} 5600+$ System (Sciex, Foster City, CA, USA) equipped with a dual source was used. ESI interface was employed for sample injection and the atmospheric-pressure chemical ionization interface (APCI) for calibrant delivery. The ESI source was operated in positive mode. The parameters applied were 60 psi of gas 1 and 2,; 30 psi of curtain gas,; an ionspray voltage of $4500 \mathrm{~V}$; a declustering potential of $80 \mathrm{~V}$ and a temperature of $575^{\circ} \mathrm{C}$. Nitrogen was used as nebulizer, curtain and collision gas. The acquisition method consisted in a full-scan survey (TOF-MS) followed by four TOF-MS/MS scans carried out by Information Dependent Acquisition (IDA) of the four more intense ions in each TOF-MS scan. Scanned mass range was from 50 to $1000 \mathrm{~m} / \mathrm{z}$, either in TOF-MS (resolving power of 30000) or TOF-MS/MS experiments. An accumulation time of $250 \mathrm{~ms}$ was applied in TOF-MS and $100 \mathrm{~ms}$ for IDA scan. IDA 
232 criteria considered dynamic background subtraction. Collision energy of $30 \mathrm{eV}$ with a \pm $23315 \mathrm{eV}$ spread was used in MS/MS fragmentation. Data acquisition was carried out by 234 Analyst TF 1.5, and data processing by PeakView ${ }^{\mathrm{TM}} 2.2$ and MasterView 1.1.

235

236

237

238

239

240

241

242

243

244

245

246

247

248

249

250

251

252

253

254

255

256

257

258

259

260

261 262

\subsection{Suspect screening strategy}

A suspect list including 47 possible transformation and biotransformation products of CBZ was built according to the previously reported TPs in literature generated by diverse decontamination wastewater treatments and biological processes (Table S1). As first step of data processing, a reduction of the number of peaks for a reliable identification was carried out by applying a peak intensity threshold $\geq 1000 \mathrm{cps}$, a S/N ratio $\geq 10$ and the absence of the mass in the control sample (blank matrix). After that, the criteria adopted for a tentative identification was a mass accuracy error $\leq 5 \mathrm{ppm}$ of the precursor ion and an isotope ratio difference $\leq 10 \%$. The MS/MS information was compared with spectra reported in literature, MassBank ("MassBank Database," n.d.) and ChemSpider ("ChemSpider Database," n.d.) databases; for which a minimum score of $80 \%$ and presence of at least two fragments with an accurate mass error $\leq 5 \mathrm{ppm}$ were considered acceptable. Final confirmation of tentative identified compounds was adopted when the retention time (Rt) of the standard in matrix differed less than \pm 0.1 min and the MS/MS spectra matched.

The TPs tentatively identified were grouped according to the confidence levels proposed by Schymanski et al. (Schymanski et al., 2014). Level 4 included TPs for which enough MS/MS fragmentation information was not acquired and, consequently, no structure could be suggested. Level 3 was adopted for those compounds whose MS/MS information matched with literature or libraries, but different structures could be proposed. In Level 2 were accommodated compounds with enough MS/MS and experimental context data to propose a unique probable structure. Finally, Level 1 was considered for TPs confirmed by the unequivocal information of Rt and MS/MS fragmentation of the purchased analytical standard.

\subsection{Methods validation}

Both QuEChERS-based and PLE+SPE, procedures applied in this study for the extraction of CBZ and TPs in plant material and peat were validated for a set of 5 
compounds: CBZ, EPOX, ACRI, ACRO and OX. The validation was carried out in terms of linearity, limits of quantification (LOQs), trueness (recoveries) and precision (relative standard deviations, RSD). For validation purposes, control samples of lettuce and peat were used as blanks.

267 Linearity was studied by spiking matrix blank extracts at 11 different concentrations ranging from 0.1 to $200 \mathrm{ng} \mathrm{g}^{-1}$. Adequate determination coefficients $\left(\mathrm{R}^{2}\right)$ were considered acceptable when $R^{2} \geq 0.990$. Recoveries and precision $(n=3)$ were evaluated by spiking blank samples (20 $\mathrm{ng} \mathrm{g}^{-1}$ in peat and $10 \mathrm{ng} \mathrm{g}^{-1}$ in lettuce). LOQs were experimentally calculated as the lowest concentration level spiked in blank matrix extract which fulfill the requirements of analyte confirmation. In Table S2 is compiled the information of both validation methodologies.

\section{Results and Discussion}

\subsection{Identification of CBZ TPs by suspect screening}

276 Following the suspect screening approach described above (Section 2.5.), a total of 24

277 TPs out of the 47 included in the suspect list were tentatively identified in some of the analyzed samples (irrigation water, peat or lettuces). The list of candidates and chromatographic and identification information is presented in Table 1.

One of the main difficulties regarding TPs identification is the differentiation between isomers or compounds with closely related structures, which can show the same accurate mass and elemental composition and even very similar MS/MS fragmentation due to their related structures. This can lead to flimsy or erroneous tentative identifications, even when an adequate chromatographic separation is carried out. This is the case of the 12 TPs classified in Level 3, for which varied structures could be proposed in each case.

An example regarding difficulties on appropriate identification of TPs in absence of standards was the allocation of structures for TPs 253A-D, with extraction mass $\mathrm{m} / \mathrm{z}$ 253.0971 for the $[\mathrm{M}+\mathrm{H}]^{+}$. The elemental composition, $\mathrm{C}_{15} \mathrm{H}_{12} \mathrm{~N}_{2} \mathrm{O}_{2}$, corresponded to the addition of one oxygen atom to the structure of CBZ and all of them presented the same fragmentation pattern. Fig. 1 shows the extracted ion chromatogram (XIC: 253.0971 $\mathrm{m} / \mathrm{z}$ ) and MS/MS spectra of TPs 253B-D in an irrigation water sample, where the 
similarity of the MS/MS spectra for the three compounds can be appreciated. Among the structures found according to the proposed formula (Table S1), the fragmentation pattern matched well with the spectra of the isomers typically produced by the monohydroxylation of CBZ (OH-CBZ) at different positions, as proposed by several authors (Ahmed and Chiron, 2014; Brezina et al., 2017; Hübner et al., 2014; Jelic et al., 2013; Li et al., 2013; Liu et al., 2016; Zhang et al., 2015; Zhu et al., 2016). Up to three isomers have been reported with hydroxylation at positions 2, 3 and 10. However, analysis of the available analytical standards allowed confirmation (Level 1) of TP 253C as EPOX (Ahmed and Chiron, 2014; Hübner et al., 2014; Li et al., 2013; Liu et al., 2016; Zhang et al., 2015; Zhu et al., 2016) and TP 253D as OX (Brezina et al., 2017), as it is shown in Fig. 1 . In this case, only the Rt comparison with the analytical standard allowed to distinguish both compounds. 253B was then tentatively assigned as a monohydroxy derivative, but the Rt and spectral information available was not enough to clarify the position of the hydroxylation in the ring. Therefore, TP 253B was kept in Level 3. TP 253A, also presented the same molecular formula and isotopic profile and could be tentatively proposed as a second $\mathrm{OH}-\mathrm{CBZ}$ isomer, but due to its low intensity, not enough product ions with significant intensities and exact mass data were acquired. For this reason, it was considered in identification Level 4.

A similar situation was observed for TP $269\left(\mathrm{~m} / z, 269.0920, \mathrm{C}_{15} \mathrm{H}_{12} \mathrm{~N}_{2} \mathrm{O}_{3}\right)$. Up to five peaks, TPs 269 A-E were detected. TP 269B remained in Level 4 by the same reason already exposed for TP 253A. The other four peaks presented similar characteristic fragments at $\mathrm{m} / \mathrm{z} 251.0815, \mathrm{~m} / \mathrm{z} 208.0757$ and $\mathrm{m} / \mathrm{z}$ 180.0808. The elemental composition, with two additional oxygen atoms with respect to CBZ, was in accordance with the formation of dihydroxy-CBZ derivatives proposed by Hübner et al (Hübner et al., 2014), and TP 269A and 269C were tentatively proposed as dihydroxylated isomers. However, other structures with alike fragments have also been reported in literature by Ahmed and Chiron (2014), Jelic et al., (2013) and Zhu et al., 2016(see Table S1). The hydroxylation of OX intermediate proposed by Jelic et al. (Jelic et al., 2013) match with the mass spectrum of TP 269D (Fig. S2A), which shows the characteristic fragment at $m / z$ 196.0757, corresponding to the formation of hydroxyl acridine $\left(\mathrm{C}_{13} \mathrm{H}_{9} \mathrm{NO}\right)$. However, some differences in the spectrum reported for 11-OH-OX (Jelic et al., 2013) can be explained by the different position of the $\mathrm{OH}$ group, as it is proposed in Fig. S2. On the other hand, the absence of the diagnostic fragment at $\mathrm{m} / z 196.0757$ in the mass 
329

330

331

332

333

334

335

336

337

338

339

340

341

342

343

344

345

346

347

348

349

350

351

352

353

354

355

356

357

358

359

360

361

362

spectrum of TP 269E (Fig. S2B) suggested a different structure for this compound. The alternative proposed by Ahmed and Chiron corresponds to the hydroxylation of 9formylacridine-10 $(9 \mathrm{H})$-carboxamide (Ahmed and Chiron, 2014), which can be plausible and supported by the successive losses of CHNO ( $/ 2 / z$ 226.0863), $\mathrm{H}_{2} \mathrm{O}(\mathrm{m} / z$ 208.0757) and $\mathrm{CO}(\mathrm{m} / \mathrm{z}$ 180.0808) observed in the mass spectra (Fig. S2B). A subsequent hydroxylation of TP 269E would be consistent with the formation of dihydroxy derivatives also identified as TP 285A and B (Fig. S3).

Identification of TPs 208A and 208B $\left(\mathrm{m} / \mathrm{z}, 208.0756 ; \mathrm{C}_{14} \mathrm{H}_{9} \mathrm{NO}\right)$, could not be carried out. Two structures could fit with this $\mathrm{m} / \mathrm{z}$ corresponding to 9 -acridine-carboxaldehyde (Hübner et al., 2014; Liu et al., 2016; Seiwert et al., 2015; Zhang et al., 2015; Zhu et al., 2016), which was discarded by the analysis of the analytical standard, and the human metabolite CBZ iminoquinone (Brezina et al., 2017), which shared a characteristic product ion at $m / z 152.0495\left(\mathrm{C}_{11} \mathrm{H}_{5} \mathrm{~N}\right)$, with TP 208B. However, this evidence was too weak for the allocation of the CBZ iminoquinone structure and both compounds remained in Level 4.

TPs 224A (Rt $4.7 \mathrm{~min}$ ) and 224B (Rt $22.7 \mathrm{~min}$ ) were detected at $\mathrm{m} / \mathrm{z} 224.0706$ $\left(\mathrm{C}_{14} \mathrm{H}_{9} \mathrm{NO}_{2}\right)$. Both presented the same MS/MS fragments. Some authors have associated this formula to varied structures (Brezina et al., 2017; Hübner et al., 2014; Jelic et al., 2013; Li et al., 2013; Riemenschneider et al., 2017), describing common product ions in many cases (Table S1). One of the most plausible ones for TP 224A, due to its polar chromatographic behavior, was 9-acridinecarboxylic acid, which was confirmed by the analytical standard. The retention time behavior of TP 224B could match with varied structures. However, based on the MS/MS spectrum, the compound was tentatively proposed as acridone- $\mathrm{N}$-carbaldehyde, according with $\mathrm{Li}$ et al. ( $\mathrm{Li}$ et al., 2013) in a study about identification and kinetic of metabolites of CBZ in soil. The similarity with the fragmentation pattern of acridone after the loss of $-\mathrm{CO}\left(\mathrm{m} / \mathrm{z}, 196.0750 ; \mathrm{C}_{13} \mathrm{H}_{9} \mathrm{NO}\right)$ supported the proposal of this structure at Level 3.

In the case of TPs 267A and 267B $\left(\mathrm{m} / z\right.$ 267.0764; $\left.\mathrm{C}_{15} \mathrm{H}_{10} \mathrm{~N}_{2} \mathrm{O}_{3}\right)$, only the first one was tentatively proposed as 11-keto oxcarbazepine, based on the MS/MS fragmentation pattern reported by Jelic et al. (2013) and Koba et al. (2016). Many other structures have been reported for TPs with $m / z$ 267.0764, however not enough evidences have 
363

364

365

366

367

368

369

370

371

372

373

374

375

376

377

378

379

380

381

382

383

384

385

386

387

388

389

390

391

392

393

394

395

396

been found that support a structure assignation. Consequently, TP 267B was not assigned (Level 4).

TPs 271A and B, also presented very similar fragmentation, which matched well with that proposed by Jelic et al. (Jelic et al., 2013) and Hübner et al. (Hübner et al., 2014) for 10,11-dihydro-10,11-dihydroxycarbamazepine. Li et al. (Li et al., 2013) also confirmed this compound by comparing with an authentic standard and reported the presence of the cis and trans stereoisomers, which could correspond with the two peaks observed. The assignation of this structure was also reinforced with the identification of TP $287\left(m / z\right.$ 287.1026; $\left.\mathrm{C}_{15} \mathrm{H}_{14} \mathrm{~N}_{2} \mathrm{O}_{4}\right)$, which could correspond with a further hydroxylation of the benzene ring in TP 271.

Despite of the general absence of TPs MS/MS spectra in spectral libraries and databases, attributable to the scarce availability of commercial analytical standards, some of the TPs under study could be identified by this way. This was the case of TP $194\left(\mathrm{~m} / z\right.$ 194.0964, $\left.\mathrm{C}_{14} \mathrm{H}_{11} \mathrm{~N}\right)$, which matched with iminostilbene structure (94\% score) in MassBank, or TP $239\left(\mathrm{~m} / z, 239.1179, \mathrm{C}_{15} \mathrm{H}_{14} \mathrm{~N}_{2} \mathrm{O}\right)$, which revealed a $90 \%$ of spectral score match with 10,11-dihydrocarbamazepine in ChemSpider database. Both were confirmed by subsequent standard acquisition and analysis.

Although spectral and context evidences pointed out a tentative structure proposal for most of the compounds investigated, a definite confirmation by analytical standard (Level 1) was only obtained for 7 TPs namely ACRI, ACRO, EPOX, OX, TP 194 (iminostilbene), TP 224A (9-acridinecarboxylic acid) and TP 239 (10-11 Dihydrocarbamazepine).

3.2 Identification of CBZ TPs in irrigation water, peat and lettuce leaves

It is already known that CBZ is a recalcitrant compound whose removal is not efficient by conventional treatments, leading to its constant detection in WWTP effluents (Campos-Mañas et al., 2017). In this study, the removal of CBZ in water after UVC treatment described in the experimental section was about $20 \%$, as it is shown in Fig. S4. However, despite its persistence, a total of $22 \mathrm{CBZ}$ TPs were identified in the treated water $(\mathrm{SW}+\mathrm{CBZ}+\mathrm{UVC})$, which was used in the irrigation assays (see Table 2). 
In general, peak areas were comparable in each irrigation batch, showing a repetitive pattern of TPs formation. The most abundant TP found in treated water was EPOX followed by TP 253B (OH-CBZ), TP 194 (iminostilbene) and ACRI, which were detected from the second minute of treatment (Fig. S5). Overall, TP abundances increased with treatment time due to the persistence of CBZ. Alternatively, no TPs were detected in the irrigation water containing CBZ, which had not undergone any treatment.

404

For peat and lettuces irrigated with SW, neither CBZ nor any of its TPs were observed. Regarding samples irrigated with $\mathrm{SW}+\mathrm{CBZ}$ and $\mathrm{SW}+\mathrm{CBZ}+\mathrm{UVC}$, the results showed that almost identical TPs were detected in both irrigation experiments. As can be seen in Table 2, 10 TPs were identified in peat irrigated with untreated water containing CBZ and 11 in peat irrigated with the treated water, while 9 TPs were found in lettuces regardless of the water used for irrigation. These data suggest that UVC treatment did not contribute to the presence of different TPs with respect to those formed by the transformation of $\mathrm{CBZ}$ in peat or lettuce. TPs formation was also possible by the only presence of CBZ in irrigation water. This is in agreement with the results found by Riemenschneider et al. (Riemenschneider et al., 2017) for tomato plants cultivated under hydroponic conditions irrigated with a nutrient solution containing only CBZ.

417 In regard to the abundances of the identified TPs, these were higher, in general, in peats 418 irrigated with UVC-treated water since the treatment promotes the TPs formation. Fig. 2 shows the evolution on the abundances of the CBZ TPs detected in lettuce and peat samples during the plant growth. Higher differences were observed in TPs 271C and 285B. This pattern was also observed when concentrations of EPOX, ACRI and ACRO were quantitatively evaluated. As shown in Table 3, slightly higher TP concentration values were obtained from peat irrigated with treated water, although this correlation was not always observed in lettuce. For the vegetable, the CBZ TP concentrations were higher in samples irrigated with SW+CBZ (Table 3 and Fig. 2). This demonstrates the necessity to develop efficient wastewater treatments able to completely remove recalcitrant compounds as $\mathrm{CBZ}$ in order to prevent their plant metabolization, which may lead to the detection of TPs in edible parts of crops. TP concentrations followed the order EPOX > ACRO > ACRI in every commodity and experimental irrigation test. EPOX has been reported as the most abundant TP in soils (Koba et al., 2016) and 
tomato plants (Riemenschneider et al., 2017) exposed to CBZ for long periods. In

432

433

434

435

436

437

438

439

440

441

442

443

444

445

446

447

448

449

450

451

452

453

454

455

456

457

458

459

460

461

462

463

464

general, TPs did not show biodegradability but a clear accumulation along sampling events was detected (Table 3), highlighting the accumulation of EPOX in both type of samples and irrigation tests. This accumulation can be explained in part by the increase in the transpiration rate associated with the growth of the lettuce plant (Dodgen et al., 2015), although other factors, such as the plant's physiology, environmental conditions and TPs physicochemical properties (i.e. lipophilicity and electrical charge), can also contribute to this behavior (Christou et al., 2017).

In Table 2, it is also shown two TPs (TP $285 \mathrm{~A}$ and B) detected in peat samples and not in water. Therefore, it can be hypothesized that the formation of these TPs can be attributed to the metabolism of $\mathrm{CBZ}$ in peat since none of them was previously identified in UVC-treated irrigation water. The absence of TP 285A in peat irrigated with $\mathrm{SW}+\mathrm{CBZ}$ could be attributable to a lower formation of this isomer. Concerning lettuce samples, TP 269C and 271B were found only in lettuce leaves. They could be supposedly generated by the metabolization of CBZ in plant material. Furthermore, their absence in peat samples may also be attributed to their further mineralization or degradation to other TPs in peat.

Some of the CBZ TPs investigated in this study as ACRI, ACRO, EPOX and TP 267A, have already been reported in agricultural soils and soilless cultures (Koba et al., 2016; Li et al., 2013; Martínez-Piernas et al., 2018a). As well, ACRI, ACRO, EPOX, OX, TP 224 A (9-acridinecarboxylic acid), TP 239 (10-11 dihydrocarbamazepine), TP 253 A/B, TP 271 A/B have been identified in plant tissues as roots, stems or leaves (MartínezPiernas et al., 2018b; Riemenschneider et al., 2017, 2016), the suspect screening approach applied has allowed the tentative identification of new TPs not previously found neither in agricultural substrate or soils nor in vegetable matrices. To the authors' knowledge, this study reports for the first time the identification of TP 194 (iminostilbene), TP 271B and TPs 285A/B in an agricultural substrate as peat, as well as TP 239 and TPs 271A/B in in a lettuce crop.

One of the main challenges regarding reuse of WW for agricultural purposes is having more knowledge about the formation and occurrence of TPs more toxic than parent compounds. Some of the TPs identified in lettuce samples in this study, as ACRI and 
465 ACRO have exhibited more toxicity, when both analytes were found mixed, than CBZ 466 itself across multiple trophic levels (Donner et al., 2013). Besides, in a genotoxicity 467 prediction study carried out by Brezina et al. (Brezina et al., 2017), CBZ derivates such 468 as 9-acridinecarboxylic acid (TP 224A) showed higher toxicological relevance than 469 CBZ. On the other hand, EPOX has potential genotoxic carcinogenicity (Houeto et al., 470 2012). In this outline, it is necessary not only a toxicological evaluation of parent 471 compounds but also taking into account mixture toxicities to evaluate human health and 472 environmental impacts derived from reuse of RWW in agriculture.

\section{4. Conclusions}

474 This work presents the first evaluation of the behavior of CBZ TPs formed by a 475 conventional UVC water treatment in an agricultural system. The UVC-treated water 476 was used to irrigate a lettuce crop grown in peat under controlled conditions. The fate of 477 TPs in the latter was compared to the TPs generated due to CBZ degradation processes 478 in both commodities. For TPs identification, a rapid and semi-automatic suspect 479 screening approach was applied to peat and lettuce samples by LC-QTOF-MS. The 480 suspect screening strategy revealed the presence of up to 11 CBZ TPs in peat and 9 in 481 lettuce leaves, showing the potential of the suspect screening approach. No substantial 482 differences regarding TPs formation or fate were found derived from the diverse 483 irrigations. In any case, TPs were likely to reach the edible parts of crops, so 484 highlighting the need for efficient wastewater treatments able to remove OMC to avoid 485 their translocation to plant tissues. This study has contributed to a better understanding 486 of the fate of CBZ TPs and results obtained can serve as a basis to extend the study of 487 these TPs to field crops, grown under diverse conditions. As a general remark, more 488 knowledge regarding OMC TPs structure and behavior must be obtained in order to 489 fully assess the risk associated with their discharge in the environment and human 490 consumption due to reuse practices in agriculture.

492 5. Acknowledgments

493 The authors acknowledge the COST Action ES1403 NEREUS "New and emerging 494 challenges and opportunities in wastewater reuse", supported by COST (European 495 Cooperation in Science and Technology). A. B. Martínez-Piernas gratefully 496 acknowledge the financial support she received during a Short-Term Scientific Mission 
497

498

499

500

501

502

503

504

505

506

507

508

509

510

511

512

513

514

515

516

517

518

519

520

521

522

523

524

525

526

527

528

529

(STSM) offered by the COST Action ES1403 and the Cooperation agreement between the University of Almería and PSA-CIEMAT for the financial support of her $\mathrm{PhD}$ scholarship.

\section{References}

Ahmed, M.M., Chiron, S., 2014. Solar photo-Fenton like using persulphate for carbamazepine removal from domestic wastewater. Water Res. 48, 229-236. https://doi.org/10.1016/j.watres.2013.09.033

Ambrósio, A.F., Soares-da-Silva, P., Carvalho, C.M., Carvalho, A.P., 2002. Mechanisms of action of carbamazepine and its derivatives, oxcarbazepine, BIA 2093, and BIA 2-024. Neurochem. Res. 27, 121-130. https://doi.org/10.1023/A:1014814924965

American Public Health Association, American Water Works Association, W.P.C.F., 2012. Standard methods for the examination of water and wastewater / prepared and published jointly by American Public Health Association, American Water Works Association, Water Pollution Control Federation; joint editorial board 25 editions of this work Thumbnail Title, Author, Edition Date[Sorted decending], 22nd ed. American Public Health Association, Washington, D.C.

Bahlmann, A., Brack, W., Schneider, R.J., Krauss, M., 2014. Carbamazepine and its metabolites in wastewater: Analytical pitfalls and occurrence in Germany and Portugal. Water Res. 57, 104-114. https://doi.org/10.1016/j.watres.2014.03.022

Brezina, E., Prasse, C., Meyer, J., Mückter, H., Ternes, T.A., 2017. Investigation and risk evaluation of the occurrence of carbamazepine, oxcarbazepine, their human metabolites and transformation products in the urban water cycle. Environ. Pollut. 225, 261-269. https://doi.org/10.1016/j.envpol.2016.10.106

Campos-Mañas, M.C., Plaza-Bolaños, P., Sánchez-Pérez, J.A., Malato, S., Agüera, A., 2017. Fast determination of pesticides and other contaminants of emerging concern in treated wastewater using direct injection coupled to highly sensitive ultra-high performance liquid chromatography-tandem mass spectrometry. J. Chromatogr. A 1507, 84-94. https://doi.org/10.1016/j.chroma.2017.05.053

Carter, L.J., Williams, M., Martin, S., Kamaludeen, S.P.B., Kookana, R.S., 2018. Sorption, plant uptake and metabolism of benzodiazepines. Sci. Total Environ. 628-629, 18-25. https://doi.org/10.1016/j.scitotenv.2018.01.337 
530 ChemSpider Database [WWW Document], n.d. URL http://www.chemspider.com/

531 Chen, F., Ying, G.G., Kong, L.X., Wang, L., Zhao, J.L., Zhou, L.J., Zhang, L.J., 2011.

532 Distribution and accumulation of endocrine-disrupting chemicals and

533

534

535

536

537

538

539

540

541

542

543

544

545

546

547

548

549

550

551

552

553

554

555

556

557

558

559

560

561

562

563 pharmaceuticals in wastewater irrigated soils in Hebei, China. Environ. Pollut. 159, 1490-1498. https://doi.org/10.1016/j.envpol.2011.03.016

Christou, A., Karaolia, P., Hapeshi, E., Michael, C., Fatta-Kassinos, D., 2017. Longterm wastewater irrigation of vegetables in real agricultural systems: Concentration of pharmaceuticals in soil, uptake and bioaccumulation in tomato fruits and human health risk assessment. Water Res. 109, 24-34. https://doi.org/10.1016/j.watres.2016.11.033

Dai, C.M., Zhou, X.F., Zhang, Y.L., Duan, Y.P., Qiang, Z.M., Zhang, T.C., 2012. Comparative study of the degradation of carbamazepine in water by advanced oxidation processes. Environ. Technol. (United Kingdom) 33, 1101-1109. https://doi.org/10.1080/09593330.2011.610359

Deng, J., Shao, Y., Gao, N., Xia, S., Tan, C., Zhou, S., Hu, X., 2013. Degradation of the antiepileptic drug carbamazepine upon different UV-based advanced oxidation processes in water. Chem. Eng. J. 222, 150-158. https://doi.org/10.1016/j.cej.2013.02.045

Dodgen, L., Ueda, A., Wu, X., Parker, D., Gan, J., 2015. Effect of transpiration on plant accumulation and translocation of PPCP/EDCs. Environ. Pollut.198, 144-153. https:// 10.1016/j.envpol.2015.01.002

Donner, E., Kosjek, T., Qualmann, S., Kusk, K.O., Heath, E., Revitt, D.M., Ledin, A., Andersen, H.R., 2013. Ecotoxicity of carbamazepine and its UV photolysis transformation products. Sci. Total Environ. 443, 870-876. https://doi.org/10.1016/j.scitotenv.2012.11.059

Fent K., 2008. Effects of Pharmaceuticals on Aquatic Organisms, in: Kümmerer K. (Ed.), Pharmaceuticals in the Environment. Springer, Heidelberg, pp. 175-203. https://doi.org/10.1007/978-3-540-74664-5_12

Ghasemian, S., Nasuhoglu, D., Omanovic, S., Yargeau, Y., 2017. Photoelectrocatalytic degradation of pharmaceutical carbamazepine using Sb-doped $\mathrm{Sn}_{80 \%}-\mathrm{W}_{20 \% \text {-oxide }}$ electrodes. Sep. Purif. Technol., 188, 52-59. https://doi.org/10.1016/j.seppur.2017.07.007

Houeto, P., Carton, A., Guerbet, M., Mauclaire, A.C., Gatignol, C., Lechat, P., Masset, D., 2012. Assessment of the health risks related to the presence of drug residues in 
Pharmacol. 62, 41-48. https://doi.org/10.1016/j.yrtph.2011.11.012

Hübner, U., Seiwert, B., Reemtsma, T., Jekel, M., 2014. Ozonation products of carbamazepine and their removal from secondary effluents by soil aquifer treatment - Indications from column experiments. Water Res. 49, 34-43. https://doi.org/10.1016/j.watres.2013.11.016

Huynh, K., Banach, E., Reinhold, D., 2018. Transformation, Conjugation, and Sequestration Following the Uptake of Triclocarban by Jalapeno Pepper Plants. J. Agric. Food Chem. 66, 4032-4043. https://doi.org/10.1021/acs.jafc.7b06150

Jelic, A., Michael, I., Achilleos, A., Hapeshi, E., Lambropoulou, D., Perez, S., Petrovic, M., Fatta-Kassinos, D., Barcelo, D., 2013. Transformation products and reaction pathways of carbamazepine during photocatalytic and sonophotocatalytic treatment. J. Hazard. Mater. 263, 177-186. https://doi.org/10.1016/j.jhazmat.2013.07.068

Jelić, A., Petrović, M., Barceló, D., 2009. Multi-residue method for trace level determination of pharmaceuticals in solid samples using pressurized liquid extraction followed by liquid chromatography/quadrupole-linear ion trap mass spectrometry. Talanta 80, 363-371. https://doi.org/10.1016/j.talanta.2009.06.077

Kinney, C.A., Furlong, E.T., Kolpin, D.W., Burkhardt, M.R., Zaugg, S.D., Werner, S.L., Bossio, J.P., Benotti, M.J., 2008. Bioaccumulation of pharmaceuticals and other anthropogenic waste indicators in earthworms from agricultural soil amended with biosolid or swine manure. Environ. Sci. Technol. 42, 1863-1870. https://doi.org/10.1021/es702304c

Kinney, C.A., Furlong, E.T., Werner, S.L., Cahill, J.D., 2006. Presence and distribution of wastewater-derived pharmaceuticals in soil irrigated with reclaimed water. Environ. Toxicol. Chem. 25, 317-326. https://doi.org/10.1897/05-187R.1

Koba, O., Golovko, O., Kodesova, R., Klement, A., Grabic, R., 2016. Transformation of atenolol, metoprolol, and carbamazepine in soils: The identification, quantification, and stability of the transformation products and further implications for the environment. Environ. Pollut. 218, 574-585. https://doi.org/10.1016/j.envpol.2016.07.041

Larivière, A., Lissalde, S., Soubrand, M., Casellas-Français, M., 2017. Overview of Multiresidues Analytical Methods for the Quantitation of Pharmaceuticals in Environmental Solid Matrixes: Comparison of Analytical Development Strategy 
598

599

600

601

602

603

604

605

606

607

608

609

610

611

612

613

614

615

616

617

618

619

620

621

622

623

624

625

626

627

628

629

630

631

for Sewage Sludge, Manure, Soil, and Sediment Samples. Anal. Chem. 89, 453-465. https://doi.org/10.1021/acs.analchem.6b04382

Li, J., Dodgen, L., Ye, Q., Gan, J., 2013. Degradation kinetics and metabolites of carbamazepine in soil. Environ. Sci. Technol. 47, 3678-3684. https://doi.org/10.1021/es304944c

Liu, N., Lei, Z.D., Wang, T., Wang, J.J., Zhang, X.D., Xu, G., Tang, L., 2016. Radiolysis of carbamazepine aqueous solution using electron beam irradiation combining with hydrogen peroxide: Efficiency and mechanism. Chem. Eng. J. 295, 484-493. https://doi.org/10.1016/j.cej.2016.03.040

Malato, S., Fernández-Ibáñez, P., Maldonado, M.I., Blanco, J., Gernjak, W., 2009. Decontamination and disinfection of water by solar photocatalysis: Recent overview and trends. Catal. Today 147, 1-59. https://doi.org/10.1016/j.cattod.2009.06.018

Martínez-Piernas, A.B., Plaza-Bolaños, P., García-Gómez, E., Fernández-Ibáñez, P., Agüera, A., 2018a. Determination of organic microcontaminants in agricultural soils irrigated with reclaimed wastewater: Target and suspect approaches. Anal. Chim. Acta 1030, 115-124. https://doi.org/10.1016/j.aca.2018.05.049

Martínez-Piernas, A.B., Polo-López, M.I., Fernández-Ibáñez, P., Agüera, A., 2018b. Validation and application of a multiresidue method based on liquid chromatography-tandem mass spectrometry for evaluating the plant uptake of 74 microcontaminants in crops irrigated with treated municipal wastewater. J. Chromatogr. A 1534, 10-21. https://doi.org/10.1016/j.chroma.2017.12.037

MassBank Database [WWW Document], n.d. URL https://massbank.eu/

Miralles-Cuevas, S., Darowna, D., Wanag, A., Mozia, S., Malato, S., Oller, I., 2017. Comparison of UV/H2O2, UV/S2O82-, solar/Fe(II)/H2O2 and solar/Fe(II)/S2O82- at pilot plant scale for the elimination of micro-contaminants in natural water: An economic assessment. Chem. Eng. J. 310, 514-524. https://doi.org/10.1016/j.cej.2016.06.121

Riemenschneider, C., Al-Raggad, M., Moeder, M., Seiwert, B., Salameh, E., Reemtsma, T., 2016. Pharmaceuticals, Their Metabolites, and Other Polar Pollutants in FieldGrown Vegetables Irrigated with Treated Municipal Wastewater. J. Agric. Food Chem. 64, 5784-5792. https://doi.org/10.1021/acs.jafc.6b01696

Riemenschneider, C., Seiwert, B., Moeder, M., Schwarz, D., Reemtsma, T., 2017. Extensive Transformation of the Pharmaceutical Carbamazepine Following Uptake 
632

633

634

635

636

637

638

639

640

641

642

643

644

645

646

647

648

649

650

651

652

653

654

655

656

657

658

659

660

661

662

663

664

into Intact Tomato Plants. Environ. Sci. Technol. 51, 6100-6109. https://doi.org/10.1021/acs.est.6b06485

Schollée, J.E., Schymanski, E.L., Avak, S.E., Loos, M., Hollender, J., 2015. Prioritizing Unknown Transformation Products from Biologically-Treated Wastewater Using High-Resolution Mass Spectrometry, Multivariate Statistics, and Metabolic Logic. Anal. Chem. 87, 12121-12129. https://doi.org/10.1021/acs.analchem.5b02905

Schymanski, E.L., Jeon, J., Gulde, R., Fenner, K., Ruff, M., Singer, H.P., Hollender, J., 2014. Identifying small molecules via high resolution mass spectrometry: Communicating confidence. Environ. Sci. Technol. 48, 2097-2098. https://doi.org/10.1021/es5002105

Seiwert, B., Golan-Rozen, N., Weidauer, C., Riemenschneider, C., Chefetz, B., Hadar, Y., Reemtsma, T., 2015. Electrochemistry Combined with LC-HRMS: Elucidating Transformation Products of the Recalcitrant Pharmaceutical Compound Carbamazepine Generated by the White-Rot Fungus Pleurotus ostreatus. Environ. Sci. Technol. 49, 12342-12350. https://doi.org/10.1021/acs.est.5b02229

Stein, K., Ramil, M., Fink, G., Sander, M., Ternes, T.A., 2008. Analysis and sorption of psychoactive drugs onto sediment. Environ. Sci. Technol. 42, 6415-6423. https://doi.org/10.1021/es702959a

Wu, X., Dodgen, L.K., Conkle, J.L., Gan, J., 2015. Plant uptake of pharmaceutical and personal care products from recycled water and biosolids: A review. Sci. Total Environ. 536, 655-666. https://doi.org/10.1016/j.scitotenv.2015.07.129

Zhang, Q., Chen, J., Dai, C., Zhang, Y., Zhou, X., 2015. Degradation of carbamazepine and toxicity evaluation using the UV/persulfate process in aqueous solution. J. Chem. Technol. Biotechnol. 90, 701-708. https://doi.org/10.1002/jctb.4360

Zhang, Y., Geißen, S.U., Gal, C., 2008. Carbamazepine and diclofenac: Removal in wastewater treatment plants and occurrence in water bodies. Chemosphere 73, 1151-1161. https://doi.org/10.1016/j.chemosphere.2008.07.086

Zhu, Z., Chen, Y., Gu, Y., Wu, F., Lu, W., Xu, T., Chen, W., 2016. Catalytic degradation of recalcitrant pollutants by Fenton-like process using polyacrylonitrile-supported iron (II) phthalocyanine nanofibers: Intermediates and pathway. Water Res. 93, 296-305. https://doi.org/10.1016/j.watres.2016.02.035 


\section{Tables}

666 Table 1. List of CBZ TPs identified in samples, accurate mass and chromatographic information.

\begin{tabular}{lllllll}
\hline Compound & Structure & Molecular & {$[\mathrm{M}+\mathrm{H}]^{+}$} & Error & $\mathrm{Rt}$ & Product ion
\end{tabular}

(ppm) (min)

$\begin{array}{llll}\text { PI } & \text { Identification } & \text { Criteria } & \text { Reference } \\ \text { Error } & \text { level }\end{array}$

CBZ

$\mathrm{C}_{15} \mathrm{H}_{12} \mathrm{~N}_{2} \mathrm{O}$

237.1022

$-0.2 \quad 21.2$

194.0964

$\mathrm{C}_{14} \mathrm{H}_{11} \mathrm{~N}$

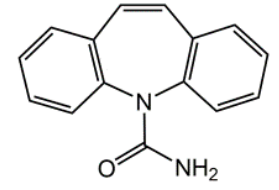

$\mathrm{C}_{14} \mathrm{H}_{9} \mathrm{~N}$

$-0.1$

-0.1
-2.5

L1

Standard

179.0730

$\mathrm{C}_{13} \mathrm{H}_{9} \mathrm{~N}$

0.3

TP 180

(ACRI)

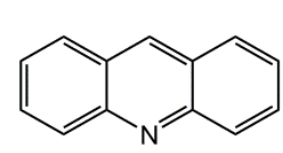

$\mathrm{C}_{13} \mathrm{H}_{9} \mathrm{~N}$

$180.0807-0.8$

12.0

178.0651

$\mathrm{C}_{13} \mathrm{H}_{7} \mathrm{~N}$

$\mathrm{C}_{11} \mathrm{H}_{7} \mathrm{~N}$

2.7
-4.7

153.0699

$\mathrm{C}_{12} \mathrm{H}_{8}$

-4.7
-4.9

TP 194

(Iminostilbene)

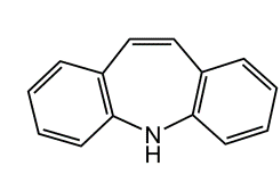

$\mathrm{C}_{14} \mathrm{H}_{11} \mathrm{~N}$

194.0964

$\begin{array}{rr}-3.7 \quad 31.8 \quad 179.0730 \\ & \\ & 167.0730 \\ & 152.0621\end{array}$

$\mathrm{C}_{13} \mathrm{H}_{9} \mathrm{~N}$
$\mathrm{C}_{12} \mathrm{H}_{9} \mathrm{~N}$

-2.0
-9.9
-3.6

L1

$\mathrm{C}_{12} \mathrm{H}_{8}$

\begin{tabular}{|c|c|}
\hline Standard & $\begin{array}{l}\text { (Ahmed } \\
\text { and } \\
\text { Chiron, } \\
\text { 2014; Li et } \\
\text { al., 2013; } \\
\text { Liu et al., } \\
\text { 2016; } \\
\text { Zhang et } \\
\text { al., 2015; } \\
\text { Zhu et al., } \\
\text { 2016) }\end{array}$ \\
\hline Standard & $\begin{array}{l}\text { (Liu et } \\
\text { al., 2016) }\end{array}$ \\
\hline
\end{tabular}




\begin{tabular}{|c|c|c|c|c|c|c|c|c|c|c|c|}
\hline $\begin{array}{l}\text { TP } 196 \\
\text { (ACRO) }\end{array}$ & 0 & $\mathrm{C}_{13} \mathrm{H}_{9} \mathrm{NO}$ & 196.0756 & -1.3 & 19.8 & $\begin{array}{l}178.0651 \\
167.073 \\
139.0542 \\
115.0542\end{array}$ & $\begin{array}{l}\mathrm{C}_{13} \mathrm{H}_{7} \mathrm{~N} \\
\mathrm{C}_{12} \mathrm{H}_{9} \mathrm{~N} \\
\mathrm{C}_{11} \mathrm{H}_{6} \\
\mathrm{C}_{9} \mathrm{H}_{6}\end{array}$ & $\begin{array}{l}-0.7 \\
-0.3 \\
-1.6 \\
2\end{array}$ & $\mathrm{~L} 1$ & Standard & $\begin{array}{l}\text { (Brezina et } \\
\text { al., 2017; } \\
\text { Hübner et } \\
\text { al., 2014; } \\
\text { Liu et al., } \\
\text { 2016; Zhu } \\
\text { et al., } \\
\text { 2016) }\end{array}$ \\
\hline $\begin{array}{l}\text { TP 208B } \\
\text { (CBZ } \\
\text { iminoquinone) }\end{array}$ & & $\mathrm{C}_{14} \mathrm{H}_{9} \mathrm{NO}$ & 208.0756 & -0.6 & 28.7 & $\begin{array}{l}180.0808 \\
178.0651 \\
152.0495\end{array}$ & $\begin{array}{l}\mathrm{C}_{13} \mathrm{H}_{9} \mathrm{~N} \\
\mathrm{C}_{13} \mathrm{H}_{7} \mathrm{~N} \\
\mathrm{C}_{11} \mathrm{H}_{5} \mathrm{~N}\end{array}$ & $\begin{array}{l}-4.9 \\
-6.3 \\
-4.4\end{array}$ & $\mathrm{~L} 4$ & $\begin{array}{l}\text { MS/MS } \\
\text { spectra } \\
\text { and RT } \\
\text { reported }\end{array}$ & $\begin{array}{l}\text { (Brezina } \\
\text { et al., } \\
\text { 2017; Liu } \\
\text { et al., } \\
\text { 2016) }\end{array}$ \\
\hline
\end{tabular}




\begin{tabular}{|c|c|c|c|c|c|c|c|c|c|c|}
\hline $\begin{array}{l}\text { TP 224B } \\
\text { (Acridone-N- } \\
\text { carbaldehyde) }\end{array}$ & $\mathrm{C}_{14} \mathrm{H}_{9} \mathrm{NO}_{2}$ & 224.0706 & 4.0 & 22.7 & $\begin{array}{l}196.0757 \\
180.0808 \\
167.0730\end{array}$ & $\begin{array}{l}\mathrm{C}_{13} \mathrm{H}_{9} \mathrm{NO} \\
\mathrm{C}_{13} \mathrm{H}_{9} \mathrm{~N} \\
\mathrm{C}_{12} \mathrm{H}_{9} \mathrm{~N}\end{array}$ & $\begin{array}{l}0.6 \\
2.9 \\
-2.1\end{array}$ & L3 & $\begin{array}{l}\text { MS/MS } \\
\text { spectra }\end{array}$ & $\begin{array}{l}\text { (Li et al., } \\
\text { 2013) }\end{array}$ \\
\hline $\begin{array}{l}\text { TP } 239 \\
(10-11 \\
\text { Dihydrocarba } \\
\text { mazepine) }\end{array}$ & $\mathrm{C}_{15} \mathrm{H}_{14} \mathrm{~N}_{2} \mathrm{O}$ & 239.1179 & 0.5 & 21.5 & $\begin{array}{l}196.1121 \\
194.0964 \\
180.0808\end{array}$ & $\begin{array}{l}\mathrm{C}_{14} \mathrm{H}_{13} \mathrm{~N} \\
\mathrm{C}_{14} \mathrm{H}_{11} \mathrm{~N} \\
\mathrm{C}_{13} \mathrm{H}_{9} \mathrm{~N}\end{array}$ & $\begin{array}{l}-5.0 \\
-1.7 \\
0.7\end{array}$ & L1 & Standard & $\begin{array}{l}\text { (Stein et } \\
\text { al., 2008) }\end{array}$ \\
\hline TP 253A & $\mathrm{C}_{15} \mathrm{H}_{12} \mathrm{~N}_{2} \mathrm{O}_{2}$ & 253.0971 & -3.8 & 13.5 & No MS/MS & & & L4 & & \\
\hline $\begin{array}{l}\text { ТP 253B } \\
\text { (OH-CBZ) }\end{array}$ & $\mathrm{C}_{15} \mathrm{H}_{12} \mathrm{~N}_{2} \mathrm{O}_{2}$ & 253.0971 & 1.4 & 17.3 & $\begin{array}{l}236.0706 \\
210.0913 \\
208,0757 \\
182.0964 \\
180.0808 \\
167.0730\end{array}$ & $\begin{array}{l}\mathrm{C}_{15} \mathrm{H}_{9} \mathrm{NO}_{2} \\
\mathrm{C}_{14} \mathrm{H}_{11} \mathrm{NO} \\
\mathrm{C}_{14} \mathrm{H}_{9} \mathrm{NO} \\
\mathrm{C}_{13} \mathrm{H}_{11} \mathrm{~N} \\
\mathrm{C}_{13} \mathrm{H}_{9} \mathrm{~N} \\
\mathrm{C}_{12} \mathrm{H}_{9} \mathrm{~N}\end{array}$ & $\begin{array}{l}4.5 \\
-0.7 \\
4.0 \\
-4.0 \\
-6.5 \\
-2.7\end{array}$ & L3 & $\begin{array}{l}\text { MS/MS } \\
\text { spectra } \\
\text { reported }\end{array}$ & $\begin{array}{l}\text { (Jelic et } \\
\text { al., 2013) }\end{array}$ \\
\hline $\begin{array}{l}\text { ТP 253C } \\
\text { (EPOX) }\end{array}$ & $\mathrm{C}_{15} \mathrm{H}_{12} \mathrm{~N}_{2} \mathrm{O}_{2}$ & 253.0971 & 0.4 & 18.2 & $\begin{array}{l}236.0706 \\
210.0913 \\
208,0757 \\
182.0964 \\
180.0808 \\
167.0730\end{array}$ & $\begin{array}{l}\mathrm{C}_{15} \mathrm{H}_{9} \mathrm{NO}_{2} \\
\mathrm{C}_{14} \mathrm{H}_{11} \mathrm{NO} \\
\mathrm{C}_{14} \mathrm{H}_{9} \mathrm{NO} \\
\mathrm{C}_{13} \mathrm{H}_{11} \mathrm{~N} \\
\mathrm{C}_{13} \mathrm{H}_{9} \mathrm{~N} \\
\mathrm{C}_{12} \mathrm{H}_{9} \mathrm{~N}\end{array}$ & $\begin{array}{l}-6.4 \\
-1.6 \\
-1.9 \\
-2.9 \\
-0.4 \\
0.9\end{array}$ & L1 & Standard & $\begin{array}{l}\text { (Ahmed } \\
\text { and } \\
\text { Chiron, } \\
\text { 2014; } \\
\text { Hübner et } \\
\text { al., 2014; } \\
\text { Li et al., } \\
\text { 2013; Liu } \\
\text { et al., } \\
2016 \text {; } \\
\text { Zhang et } \\
\text { al., 2015; } \\
\text { Zhu et al., }\end{array}$ \\
\hline
\end{tabular}




\begin{tabular}{|c|c|c|c|c|c|c|c|c|c|c|c|}
\hline $\begin{array}{l}\text { TP 253D } \\
(\mathrm{OX})\end{array}$ & 0 & $\mathrm{C}_{15} \mathrm{H}_{12} \mathrm{~N}_{2} \mathrm{O}_{2}$ & 253.0971 & 0.6 & 18.9 & $\begin{array}{l}236.0706 \\
210.0913 \\
208,0757 \\
182.0964 \\
180.0808 \\
167.0730\end{array}$ & $\begin{array}{l}\mathrm{C}_{15} \mathrm{H}_{9} \mathrm{NO}_{2} \\
\mathrm{C}_{14} \mathrm{H}_{11} \mathrm{NO} \\
\mathrm{C}_{14} \mathrm{H}_{9} \mathrm{NO} \\
\mathrm{C}_{13} \mathrm{H}_{11} \mathrm{~N} \\
\mathrm{C}_{13} \mathrm{H}_{9} \mathrm{~N} \\
\mathrm{C}_{12} \mathrm{H}_{9} \mathrm{~N}\end{array}$ & $\begin{array}{l}0.2 \\
-1.6 \\
0.1 \\
-4.0 \\
-4.3 \\
-4.5\end{array}$ & L1 & Standard & $\begin{array}{l}\text { (Brezina et } \\
\text { al., 2017) }\end{array}$ \\
\hline $\begin{array}{l}\text { TP 267A } \\
\text { (11-Keto } \\
\text { oxcarbazepine) }\end{array}$ & 0 & $\mathrm{C}_{15} \mathrm{H}_{10} \mathrm{~N}_{2} \mathrm{O}_{3}$ & 267.0764 & 1.3 & 15.3 & $\begin{array}{l}239.0815 \\
224.0706 \\
196.0757 \\
168.0808 \\
212.0706\end{array}$ & $\begin{array}{l}\mathrm{C}_{14} \mathrm{H}_{10} \mathrm{~N}_{2} \mathrm{O}_{2} \\
\mathrm{C}_{14} \mathrm{H}_{9} \mathrm{NO}_{2} \\
\mathrm{C}_{13} \mathrm{H}_{9} \mathrm{NO} \\
\mathrm{C}_{12} \mathrm{H}_{9} \mathrm{~N} \\
\mathrm{C}_{13} \mathrm{H}_{9} \mathrm{NO}_{2}\end{array}$ & $\begin{array}{l}3.6 \\
3.6 \\
4.9 \\
8.5 \\
8.5\end{array}$ & L3 & $\begin{array}{l}\text { MS/MS } \\
\text { spectra } \\
\text { reported }\end{array}$ & $\begin{array}{l}\text { (Ahmed } \\
\text { and } \\
\text { Chiron, } \\
\text { 2014; } \\
\text { Brezina et } \\
\text { al., 2017; } \\
\text { Hübner et } \\
\text { al., 2014; } \\
\text { Jelic et al., } \\
2013 ; \\
\text { Koba et } \\
\text { al., 2016; } \\
\text { Li et al., } \\
\text { 2013; Zhu } \\
\text { et al., } \\
\text { 2016) }\end{array}$ \\
\hline TP 267B & No proposal & $\mathrm{C}_{15} \mathrm{H}_{10} \mathrm{~N}_{2} \mathrm{O}_{3}$ & 267.0764 & 0.3 & 18.8 & $\begin{array}{l}224.0706 \\
222.0550 \\
206.0600 \\
196.0757 \\
167.0730\end{array}$ & $\begin{array}{l}\mathrm{C}_{14} \mathrm{H}_{9} \mathrm{NO}_{2} \\
\mathrm{C}_{14} \mathrm{H}_{7} \mathrm{NO}_{2} \\
\mathrm{C}_{14} \mathrm{H}_{7} \mathrm{NO} \\
\mathrm{C}_{13} \mathrm{H}_{9} \mathrm{NO} \\
\mathrm{C}_{12} \mathrm{H}_{9} \mathrm{~N}\end{array}$ & $\begin{array}{l}-0.5 \\
2.0 \\
-1.2 \\
0.6 \\
5.7\end{array}$ & L4 & & $\begin{array}{l}\text { (Ahmed } \\
\text { and } \\
\text { Chiron, } \\
2014 ; \\
\text { Brezina et } \\
\text { al., 2017; } \\
\text { Hübner et } \\
\text { al., 2014; } \\
\text { Jelic et }\end{array}$ \\
\hline
\end{tabular}


TP 269A

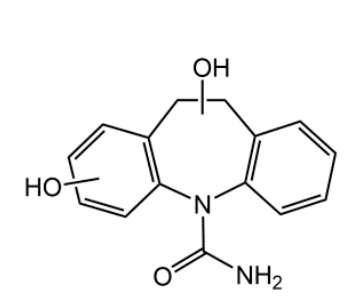

TP 269B

TP 269C

TP 269D

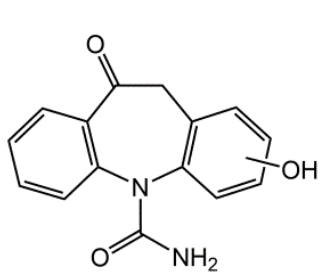

$\mathrm{C}_{15} \mathrm{H}_{12} \mathrm{~N}_{2} \mathrm{O}_{3}$
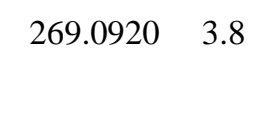
$\begin{array}{ll}12.4 & 251.0815 \\ & 208.0757\end{array}$
208.0757
180.0808
$\mathrm{C}_{15} \mathrm{H}_{10} \mathrm{~N}_{2} \mathrm{O}_{2} \quad-0.4$
$\begin{array}{ll}\mathrm{C}_{14} \mathrm{H}_{9} \mathrm{NO} & -4.8 \\ \mathrm{C}_{13} \mathrm{H}_{9} \mathrm{~N} & -3.8\end{array}$

al., 2013;

Koba et

al., 2016;

Li et al.,

2013;

Zhu et al.,

2016)
MS/MS (Ahmed
spectra
reported
and
Chiron,
2014;
Hübner et
al., 2014;
Jelic et
al., 2013)

\begin{tabular}{|c|c|}
\hline $\begin{array}{l}\text { MS/MS } \\
\text { spectra } \\
\text { reported }\end{array}$ & $\begin{array}{l}\text { (Ahmed } \\
\text { and } \\
\text { Chiron, } \\
\text { 2014; } \\
\text { Hübner et } \\
\text { al., 2014; } \\
\text { Jelic et } \\
\text { al., 2013) }\end{array}$ \\
\hline $\begin{array}{l}\text { MS/MS } \\
\text { spectra } \\
\text { reported }\end{array}$ & $\begin{array}{l}\text { (Ahmed } \\
\text { and } \\
\text { Chiron, } \\
2014 ; \\
\text { Hübner et } \\
\text { al., 2014; } \\
\text { Jelic et }\end{array}$ \\
\hline
\end{tabular}




\begin{tabular}{|c|c|c|c|c|c|c|c|c|c|c|}
\hline TP 269E & $\mathrm{C}_{15} \mathrm{H}_{12} \mathrm{~N}_{2} \mathrm{O}_{3}$ & 269.0920 & 1 & 17.5 & $\begin{array}{l}251.0815 \\
226.0863 \\
208.0757 \\
180.0808\end{array}$ & $\begin{array}{l}\mathrm{C}_{15} \mathrm{H}_{10} \mathrm{~N}_{2} \mathrm{O}_{2} \\
\mathrm{C}_{14} \mathrm{H}_{11} \mathrm{NO}_{2} \\
\mathrm{C}_{14} \mathrm{H}_{9} \mathrm{NO} \\
\mathrm{C}_{13} \mathrm{H}_{9} \mathrm{~N}\end{array}$ & $\begin{array}{l}-9.2 \\
4.2 \\
-2.4 \\
-5.4\end{array}$ & L3 & $\begin{array}{l}\text { MS/MS } \\
\text { spectra } \\
\text { reported }\end{array}$ & $\begin{array}{l}\text { (Ahmed } \\
\text { and } \\
\text { Chiron, } \\
\text { 2014; } \\
\text { Hübner et } \\
\text { al., 2014; } \\
\text { Jelic et } \\
\text { al., 2013) }\end{array}$ \\
\hline \multirow[t]{2}{*}{ TP $271 \mathrm{~A} / \mathrm{B}$} & $\mathrm{C}_{15} \mathrm{H}_{14} \mathrm{~N}_{2} \mathrm{O}_{3}$ & 271.1077 & -1.3 & 14.0 & $\begin{array}{l}253.0971 \\
236.0706 \\
210.0913 \\
208.0757 \\
180.0808\end{array}$ & $\begin{array}{l}\mathrm{C}_{15} \mathrm{H}_{12} \mathrm{~N}_{2} \mathrm{O}_{2} \\
\mathrm{C}_{15} \mathrm{H}_{9} \mathrm{NO}_{2} \\
\mathrm{C}_{14} \mathrm{H}_{11} \mathrm{NO} \\
\mathrm{C}_{14} \mathrm{H}_{9} \mathrm{NO} \\
\mathrm{C}_{13} \mathrm{H}_{9} \mathrm{~N}\end{array}$ & $\begin{array}{l}1.8 \\
-5.1 \\
2.7 \\
1.0 \\
-0.4\end{array}$ & L3 & $\begin{array}{l}\text { MS/MS } \\
\text { spectra } \\
\text { reported }\end{array}$ & $\begin{array}{l}\text { (Hübner } \\
\text { et al., } \\
2014 \text {; } \\
\text { Jelic et } \\
\text { al., 2013; } \\
\text { Li et al., } \\
\text { 2013) }\end{array}$ \\
\hline & $\mathrm{C}_{15} \mathrm{H}_{14} \mathrm{~N}_{2} \mathrm{O}_{3}$ & 271.1077 & -3.54 & 14.8 & $\begin{array}{l}236.0706 \\
210.0913 \\
180.0808\end{array}$ & $\begin{array}{l}\mathrm{C}_{15} \mathrm{H}_{9} \mathrm{NO}_{2} \\
\mathrm{C}_{14} \mathrm{H}_{11} \mathrm{NO} \\
\mathrm{C}_{13} \mathrm{H}_{9} \mathrm{~N}\end{array}$ & $\begin{array}{l}-6.4 \\
1.2 \\
1.7\end{array}$ & L3 & $\begin{array}{l}\text { MS/MS } \\
\text { spectra } \\
\text { reported }\end{array}$ & $\begin{array}{l}\text { (Hübner } \\
\text { et al., } \\
\text { 2014; } \\
\text { Jelic et } \\
\text { al., 2013) }\end{array}$ \\
\hline TP $285 \mathrm{~A}$ & $\mathrm{C}_{15} \mathrm{H}_{12} \mathrm{~N}_{2} \mathrm{O}_{4}$ & 285.0867 & 0.2 & 7.4 & $\begin{array}{l}267.0764 \\
249.0659 \\
239.0815 \\
221.0709 \\
212.0706\end{array}$ & $\begin{array}{l}\mathrm{C}_{15} \mathrm{H}_{10} \mathrm{~N}_{2} \mathrm{O}_{3} \\
\mathrm{C}_{15} \mathrm{H}_{8} \mathrm{~N}_{2} \mathrm{O}_{2} \\
\mathrm{C}_{14} \mathrm{H}_{10} \mathrm{~N}_{2} \mathrm{O}_{2} \\
\mathrm{C}_{14} \mathrm{H}_{8} \mathrm{~N}_{2} \mathrm{O} \\
\mathrm{C}_{13} \mathrm{H}_{9} \mathrm{NO}_{2}\end{array}$ & $\begin{array}{l}5.0 \\
-7.4 \\
0.4 \\
-0.2 \\
-7.9\end{array}$ & L3 & $\begin{array}{l}\text { MS/MS } \\
\text { spectra } \\
\text { reported }\end{array}$ & $\begin{array}{l}\text { (Ahmed } \\
\text { and } \\
\text { Chiron, } \\
\text { 2014) }\end{array}$ \\
\hline TP 285B & $\mathrm{C}_{15} \mathrm{H}_{12} \mathrm{~N}_{2} \mathrm{O}_{4}$ & 285.0867 & -0.5 & 13.2 & $\begin{array}{l}267.0764 \\
239.0815 \\
193.0760\end{array}$ & $\begin{array}{l}\mathrm{C}_{15} \mathrm{H}_{10} \mathrm{~N}_{2} \mathrm{O}_{3} \\
\mathrm{C}_{14} \mathrm{H}_{10} \mathrm{~N}_{2} \mathrm{O}_{2} \\
\mathrm{C}_{13} \mathrm{H}_{8} \mathrm{~N}_{2}\end{array}$ & $\begin{array}{l}-4.9 \\
-5 \\
-3.8\end{array}$ & L3 & $\begin{array}{l}\text { MS/MS } \\
\text { spectra } \\
\text { reported }\end{array}$ & $\begin{array}{l}\text { (Ahmed } \\
\text { and } \\
\text { Chiron, } \\
\text { 2014) }\end{array}$ \\
\hline
\end{tabular}


TP 287

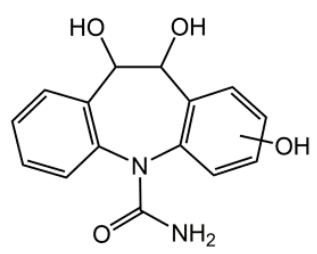

$\begin{array}{lllll}\mathrm{C}_{15} \mathrm{H}_{14} \mathrm{~N}_{2} \mathrm{O}_{4} & 287.1026 & 0.6 & 15.6 & 236.0706\end{array}$

223.0866

$\mathrm{C}_{15} \mathrm{H}_{9} \mathrm{NO}_{2}$

4.2

L3

$\mathrm{C}_{14} \mathrm{H}_{10} \mathrm{~N}_{2} \mathrm{O} \quad 0.9$

Elucidatio

210.0913

$\mathrm{C}_{14} \mathrm{H}_{11} \mathrm{NO} \quad-4$

$\mathrm{n}$

180.0808

$\mathrm{C}_{13} \mathrm{H}_{9} \mathrm{~N}$

0.7 
668 Table 2. List of the CBZ TPs detected per commodity during the vegetable growth ("X" 669 indicates presence and "-" absence of the TPs in the studied matrices).

\section{Irrigation conditions}

\begin{tabular}{|c|c|c|c|c|c|}
\hline \multirow[t]{2}{*}{ Compound } & \multicolumn{2}{|c|}{$\mathrm{SW}^{\mathrm{a}}+\mathrm{CB} \mathbf{Z}^{\mathrm{b}}$} & \multicolumn{3}{|c|}{$\mathrm{SW}+\mathrm{CBZ}+\mathrm{UVC}$} \\
\hline & $\begin{array}{c}\text { Lettuc } \\
\mathrm{e}\end{array}$ & Peat & Water & Lettuce & $\begin{array}{c}\text { Pea } \\
t\end{array}$ \\
\hline $\mathrm{CBZ}$ & $X$ & $X$ & $\mathrm{X}$ & $\mathrm{X}$ & $\mathrm{X}$ \\
\hline ACRI & X & $X$ & $X$ & $X$ & $X$ \\
\hline ТP 194 & - & X & $X$ & - & X \\
\hline ACRO & $\mathrm{X}$ & $\mathrm{X}$ & $\mathrm{X}$ & $\mathrm{X}$ & $\mathrm{X}$ \\
\hline ТP 208A & - & - & $\mathrm{X}$ & - & - \\
\hline TP 208B & - & - & $\mathrm{X}$ & - & - \\
\hline TP 224A & $\mathrm{X}$ & $\mathrm{X}$ & $\mathrm{X}$ & $\mathrm{X}$ & $\mathrm{X}$ \\
\hline ТP 224B & - & $\mathrm{X}$ & $\mathrm{X}$ & - & $\mathrm{X}$ \\
\hline ТР 239 & $\mathrm{X}$ & $\mathrm{X}$ & $\mathrm{X}$ & $\mathrm{X}$ & $\mathrm{X}$ \\
\hline TP 253A & - & - & $\mathrm{X}$ & - & - \\
\hline ТP 253B & $\mathrm{X}$ & $\mathrm{X}$ & $\mathrm{X}$ & $\mathrm{X}$ & $\mathrm{X}$ \\
\hline EPOX & $\mathrm{X}$ & $\mathrm{X}$ & $\mathrm{X}$ & $\mathrm{X}$ & $\mathrm{X}$ \\
\hline OX & - & - & $\mathrm{X}$ & - & - \\
\hline TP 267A & - & - & $\mathrm{X}$ & - & - \\
\hline TP 267B & - & - & $\mathrm{X}$ & - & - \\
\hline ТP 269A & - & - & $\mathrm{X}$ & - & - \\
\hline TP 269B & - & - & $\mathrm{X}$ & - & - \\
\hline TP 269C & $\mathrm{X}$ & - & $\mathrm{X}$ & $\mathrm{X}$ & - \\
\hline TP 269D & - & - & $\mathrm{X}$ & - & - \\
\hline TP 269E & - & - & $\mathrm{X}$ & - & - \\
\hline TP 271A & $X$ & - & $\mathrm{X}$ & $\mathrm{X}$ & - \\
\hline ТP 271B & $\mathrm{X}$ & $\mathrm{X}$ & $\mathrm{X}$ & $\mathrm{X}$ & $\mathrm{X}$ \\
\hline ТP 285A & - & - & - & - & $\mathrm{X}$ \\
\hline TP 285B & - & $\mathrm{X}$ & - & - & $\mathrm{X}$ \\
\hline ТP 287 & - & - & $\mathrm{X}$ & - & - \\
\hline
\end{tabular}

${ }^{\mathrm{a}} \mathrm{SW}$, Synthetic water; ${ }^{\mathrm{b}} \mathrm{CBZ}$, Carbamzepine; ${ }^{\mathrm{c}} \mathrm{UVC}$, Ultraviolet-C treatment 
672 Table 3. Concentrations ( $\mathrm{ng} \mathrm{g}^{-1}$ ) of $\mathrm{CBZ}$ and the validated TPs found in peat and lettuce 673 samples in both irrigation experiments.

\begin{tabular}{lllll}
\hline \multirow{2}{*}{$\begin{array}{l}\text { Week of } \\
\text { plant growth }\end{array}$} & ACRI & Peat ${ }^{\mathbf{a}}$ / Lettuce & irrigated with $\mathbf{S W}^{\mathbf{c}}+\mathbf{C B Z}^{\mathbf{d}}$ \\
\hline 2 & $\mathrm{ND}^{\mathrm{e}}(-) / \mathrm{ND}(-)$ & $28 \pm 1.2 / \mathrm{ND}(-)$ & $15 \pm 1.9 / 34 \pm 3.6$ & $1844 \pm 154 / 658 \pm 26$ \\
4 & $4.4 \pm 1 / \mathrm{ND}(-)$ & $23 \pm 6.7 / \mathrm{ND}(-)$ & $40 \pm 2.7 / 85 \pm 7.5$ & $1795 \pm 598 / 803 \pm 42$ \\
6 & $2.8 \pm 0.8 / \mathrm{ND}(-)$ & $23 \pm 3.1 / 1.3 \pm 0.26$ & $43 \pm 10 / 82 \pm 4.7$ & $2264 \pm 357 / 1112 \pm 23$ \\
8 & $3.2 \pm 1.2 / \mathrm{ND}(-)$ & $27 \pm 10 / 1.7 \pm 0.69$ & $59 \pm 4.4 / 103 \pm 3.9$ & $2260 \pm 308 / 1090 \pm 27$ \\
10 & $9.8 \pm 1.1 / 0.65 \pm 0.1$ & $28 \pm 3.3 / 5.1 \pm 1.2$ & $85 \pm 6.7 / 187 \pm 6.1$ & $3097 \pm 377 / 1749 \pm 49$ \\
\hline
\end{tabular}

\section{Peat / Lettuce irrigated with $\mathrm{SW}+\mathrm{CBZ}+\mathrm{UVC}^{\mathrm{f}}$}

\begin{tabular}{lllll}
$\begin{array}{l}\text { Week of } \\
\text { plant growth }\end{array}$ & ACRI & ACRO & EPOX & CBZ \\
\hline 2 & $13 \pm 1.7 / \mathrm{ND}(-)$ & $42 \pm 1.3 / \mathrm{ND}(-)$ & $23 \pm 0.94 / 24 \pm 1.1$ & $1000 \pm 13 / 419 \pm 9$ \\
4 & $8.3 \pm 5.5 / \mathrm{ND}(-)$ & $36 \pm 6.7 / \mathrm{ND}(-)$ & $36 \pm 1.8 / 37 \pm 1.6$ & $1381 \pm 42 / 556 \pm 16$ \\
6 & $15 \pm 4.9 / \mathrm{ND}(-)$ & $39 \pm 3.1 / 0.76 \pm 0.23$ & $51 \pm 2.4 / 57 \pm 3.5$ & $1655 \pm 16 / 828 \pm 68$ \\
8 & $21 \pm 2.3 / \mathrm{ND}(-)$ & $39 \pm 10 / 1.9 \pm 0.26$ & $66 \pm 1.6 / 79 \pm 6.1$ & $1945 \pm 76 / 889 \pm 69$ \\
10 & $23 \pm 1.4 / 0.33 \pm 0.05$ & $44 \pm 3.3 / 2.5 \pm 0.56$ & $92 \pm 2.9 / 100 \pm 11$ & $2265 \pm 22 / 1018 \pm 100$ \\
\hline
\end{tabular}

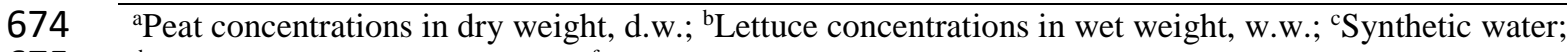

$675{ }^{\mathrm{d}}$ Carbamazepine; ${ }^{\mathrm{e}}$ Not Detected; ${ }^{\text {fUltraviolet-C }}$ treatment 


\section{Figure captions}

679 Figure 1. Extracted ion chromatogram (XIC) and MS/MS spectra of EPOX, OX and TP

680 253B from a UVC treated irrigation water sample. Comparison of the MS/MS spectra

681 of EPOX and OX with the analytical standard.

682 Figure 2. Evolution on the abundances of the CBZ TPs detected in lettuce and peat 683 samples during the plant growth. 